Meta

Journal des traducteurs

Translators' Journal

\title{
European Translators Colloquium in Straelen
}

\section{Patrick Labriola}

Volume 44, numéro 3, septembre 1999

URI : https://id.erudit.org/iderudit/003366ar

DOI : https://doi.org/10.7202/003366ar

Aller au sommaire du numéro

Éditeur(s)

Les Presses de l'Université de Montréal

ISSN

0026-0452 (imprimé)

1492-1421 (numérique)

Découvrir la revue

Citer cette note

Labriola, P. (1999). European Translators Colloquium in Straelen. Meta, 44(3),

521-522. https://doi.org/10.7202/003366ar d'utilisation que vous pouvez consulter en ligne.

https://apropos.erudit.org/fr/usagers/politique-dutilisation/ 
Laye, Camara (1966): L'enfant noir, Cambridge, CUP.

M anheim, Ralph (trad.) (1971) : Bound to Violence, Londres, Heinemann.

N ew mar k, Peter (1982) : Approaches to Translation, Oxford, Pergamon.

O u ol ogu em, Yambo (1968) : Le devoir de violence, Paris, Seuil.

Soyinka, Wole (19??) : «The Future of West African Writing",

Timot hy-A sobel e (inédit) : Bibliographie des œuvres littéraires africaines traduites.

\section{European Translators Colloquium in Straelen}

In the region of the Lower Rhine along the border of Holland, the tranquil German city of Straelen houses the European Translators Colloquium, a translation center that is a temporary home to thousands of translators from around the world. Founded in 1978 under the guidance of Samuel Beckett, Heinrich Böll, M ax Frisch, Robert M inder, and $M$ ario Wandruszka, the institute offers translators a haven to in which they can peacefully complete translation projects. Translators with at least two published translations to their name and a project from a publisher are eligible to apply for stipends to cover their costs while they reside in one of the institute's 29 furnished apartments free of charge and make use the library facilities.

Straelen, founded in 1064 and known as "the city of flowers" because of its famous local horticultural industry, is the birthplace of Elmar Tophoven, the renowned translator of Samuel Beckett, Alain Robbe-Grillet, and Nathalie Sarraute, who envisioned his home town as a sanctuary for translators and a place of international understanding. With the financial support of the state of North Rhine-Westphalia, Tophoven first established the European Translators Colloquium in 1978 in a small room next to the Town Hall, and in 1985 acquired five houses in the centre of town as a permanent home for the colloquium. In a commemorative speech at the opening of the institute in its new location, Nobel Prize winner Heinrich Böll proclaimed that something great had happened in this small town halfway between Lisbon and Helsinki on the crossroads between Holland and Germany.

The idea of conquering the Tower of Babel has long been the dream of Western civilization. In the third century B.C., 72 translators gathered on the island of Pharus near the ancient Egyptian city of Alexandria to translate the first five books of the Old Testament from Hebrew into Greek. In the Middle Ages, in the Spanish city of Toledo, scholars translated whole libraries of Arabic works into Latin and Castilian, making them suddenly accessible to the Western World. In Germany, translation has a long and respected history: Goethe rendered Voltaire into German, Hölderlin translated Sophocles, and Tieck and Schlegel made Shakespeare available to readers of German. The European Translators Colloquium has contributed to this tradition by making possible the translation of Dante's Divine Comedy (into Danish), Brecht's Baal (into Turkish), Grass's Tin Drum (into Russian), and Kleist's Penthesilea (into Bulgarian), to mention only a few. All in all, the institute has sponsored approximately 16,500 translations, including translations of works by 40 Nobel Prize winners.

The library of the European Translators Colloquium contains some 90,000 volumes, including 18,000 reference works in 270 languages and dialects from Afrikaans to Zulu, 17,000 non-fiction works, and 55,000 volumes of world literature. As the home to the world's largest source of information on fiction and non-fiction translations, the library extends throughout the institute's six buildings, overflowing into hallways and student apartments. Within the library there are 30 computers which translators may use to look up and crossreference sources. All library facilities are available to the public free of charge. Students who receive financial assistance remain at the institute for months at a time, laboring in the library day and night, attending the numerous lectures and seminars that take place at the centre, and preparing meals in the communal kitchen. Their rooms are furnished with beds, desks, lamps, bookshelves, and ample closet space.

In contrast with their counterparts in industry and big business, literary translators are so poorly paid they are forced to live at the poverty level. The average literary translator earns a maximum of 30 German marks (17 dollars) for each time-consuming page of translation. Although the European Translators Colloquium does not find translation projects for its applicants, it does award stipends in the name of donors such as the Commission of the European Union, the Robert Bosch Foundation, the German Academic Exchange Service, the Council of Europe, the Ministry for City Development, Culture and Sport in North RhineWestphalia, and the non-profit organization, Perewest. Inquiries should be made directly to the Europäisches Übersetzer-Kollegium, NordrheinWestfalen in Straelen e.V., Kuhstraße 15-19, 47638 Straelen, Tel. (02834) 1068/69, Fax (02834) 7544.

Pat rick Labriola Friedrichstraße 34, 53111 Bonn, Germany 


\section{NDLR}

Le centre de Straelen a servi en quelque sorte de modèle pour créer le Collège International des Traducteurs Littéraires (CITL) d'Arles, pour le français, le centre de Norwich, en Grande-Bretagne pour l'anglais, celui de Procida pour l'italien, celui de Visby pour le suédois et celui de Tarazona pour l'espagnol. On sait d'autre part qu'il existe quelques programmes universitaires de formation en traduction littéraires, par exemple à Düsseldorf (anglais et français) et à Münich (anglais) en Allemagne, à Bruxelles en Belgique.

\section{Collège européen des traducteurs littéraires de Seneffe}

(Sous l'égide de la Communauté française de Belgique, avec le soutien del'Union européenne)

Depuis une vingtaine d'années, il semble bien que I'on s'intéresse de plus en plus au sort du traducteur littéraire. Sans doute a-t-on enfin compris que la qualité de la traduction en général était étroitement liée au confort de cet incontournable ambassadeur culturel.

Une des initiatives allant dans ce sens est la création de Collèges de traducteurs littéraires, à ce jour au nombre de douze en Europe. Par définition le Collège est censé offrir au résident un environnement idéal lui permettant de mener à bien ses projets de traduction.

C'est en 1996 que le collège de Seneffe vit le jour, grâce aux aides financières conjointes du ministère de la Culture de la Communauté française de Belgique, et de la Commission européenne. Installées dans les dépendances rénovées du Château de Seneffe (à une trentaine de kilomètres de Bruxelles), au cœur d'un merveilleux parc de 24 hectares, ses bâtisses blanches, entourant un vaste patio agrémenté d'une fontaine, abritent 18 chambres très confortables, une bibliothèque riche de multiples ouvrages de références et d'un plateau informatique, une salle de télévision, une grande salle à manger et un très beau salon. La particularité du Collège de Seneffe est son infrastructure hôtelière: Le résident y est complètement pris en charge: logé, nourri, chauffé, blanchi, il a aussi à sa disposition un service de téléphone et de fax.

Le Collège de Seneffe accueille toutes les combinaisons linguistiques, mais donne toutefois la priorité aux traducteurs de littérature belge de langue française, qui, en sus de la prise en charge totale, bénéficient d'un per diem s'ils sont déjà en possession d'un contrat d'édition. C'est d'ailleurs dans cette optique que le Collège met à la disposition des résidents la quasi-totalité des œuvres d'écrivains belges francophones et invite régulièrement les auteurs contemporains à des séances de lectures et de séminaires. Ainsi, les traducteurs trouvent-ils ici l'occasion de rencontrer leurs auteurs et même de travailler avec eux. De surcroît, il n'est pas rare que le Collège réunisse à la même période les traducteurs d'un même auteur, voire d'une même œuvre. Dans ce cas, les échanges et les débats ainsi rendus possibles entre les traducteurs penchés sur un même texte, sont des plus fructueux.

Le Collège de Seneffe organise aussi réguliè rement des spectacles de théâtre à la seule intention de ses résidents, manière originale de faire découvrir aux traducteurs étrangers le théâtre belge, allant de Crommelynck à Verheggen en passant par Michaud et Lejeune. Ce qui ne gâte rien, c'est que ces pièces sont jouées par l'excellente troupe du Théatre-Poème, dans un lieu idyllique: Le Petit Théâtre baroque, situé dans le parc du château, et depuis sa restauration, devenu monument classé.

N'oublions pas non plus l'importance de la grande convivialité qui règne ici durant la session entre ces traducteurs venus de tous les coins du monde et réunis par un même amour du métier. Jusqu'ici, l'expérience du Collège de Seneffe a montré que les traducteurs littéraires, champions de la tolérance par essence, puisque toujours tournés vers l'Autre et au service de l'Autre, pouvaient cohabiter dans le plus grand bonheur et la plus grande joie.

Enfin, pour marquer sa reconnaissance envers ceux ou celles qui contribuent au rayonnement de la littérature belge à l'étranger par la qualité de leurs traductions, le Collège décerne chaque année un prix de traduction d'un montant de 200000 francs belges. En 1997, le prix est alléau Hollandais, Ernst van Altena, la deuxième année à une anglaise, Anne-M arie Glasheen et cette année, c'est au hongrois Janos Lackfi qu'ira la récompense.

Avis donc aux amateurs, qui, pour obtenir de plus amples renseignements, peuvent s'adresser à la directrice du Collège, Françoise Wuilmart. (cetl@compuserve.com) 